\title{
YOXO Founder Discusses the Serious Business of Play
}

\section{Daniel Forbes (University of Minnesota)}

KEYWORDS: Innovation, Learn From Leaders.

Jeff Freeland Nelson has some unusual advice for young people wanting to become entrepreneurs: major in theater instead of business. It will teach you how to make things, work with others creatively and meet very tight deadlines.

That is one of many refreshing insights that the founder and CEO of YOXO, which makes recyclable and sustainable building toys, shares in this interview with EIX's Dan Forbes. Nelson also talks about why he sees himself as an inventor rather than an entrepreneur, how he re-grouped after his first toy products were mistaken for packing materials, how he's attracted angel investors, and why he has dinner with his family every night and encourages his employees to do the same. 